\title{
Thermal Requirement of Green Gram (Vigna radiate L.) Varieties at Different Phenological Stages under Varied Weather Condition
}

\author{
B.R. Bobade ${ }^{1^{*}}$, B.V. Asewar ${ }^{2}$, S. M. Nikam ${ }^{3}$ and K.K. Dakhore ${ }^{4}$ \\ ${ }^{1}$ FASAL Agricultural Meteorology, ${ }^{2}$ Department of Agronomy, ${ }^{3}$ Department of Agricultural \\ Meteorology, ${ }^{4}$ AICRP on Agricultural Meteorology, VNMKV, Parbhani (M.S), India \\ *Corresponding author
}

\begin{tabular}{|l|}
\hline Ke y w o r d s \\
Green gram, \\
Phenophases, \\
GDD, HTU, PTU \\
\hline Article Info \\
\hline $\begin{array}{l}\text { Accepted: } \\
10 \text { November } 2019 \\
\text { Available Online: } \\
10 \text { December } 2019\end{array}$ \\
\hline
\end{tabular}

\section{A B S T R A C T}

Green gram (Vigna radiate L.) is a short day plant and generally requires fairly hot conditions for its optimum growth and yield. Crop growth and development are closely related with energy requirement parameters, such as growing degree days (GDD), photothermal unit (PTU) and Helio-thermal Units (HTU). Therefore, GDD and other agrometeorological indices requirement for different phenological stages of green gram genotypes was carried out during kharif season 2015 at experimental farm of department of Agricultural Meteorology, College of Agriculture, Parbhani. The treatment combination of three sowing dates and genotype were replicated thrice in split plot design i.e. $\mathrm{D}_{1}\left(25^{\text {th }}\right.$ $\mathrm{MW}), \mathrm{D}_{2}\left(26^{\text {th }} \mathrm{MW}\right)$ and $\mathrm{D}_{3}\left(27^{\text {th }} \mathrm{MW}\right)$ and four genotype BM-4, BPMR-145, BM-2003-2 and BM-2002-1 were sown with spacing of $30 \times 10 \mathrm{~cm}$. The gross and net plot size were $4.5 \mathrm{~m} \mathrm{x} 4.0 \mathrm{~m}$ and $3.9 \mathrm{~m} \times 3.6 \mathrm{~m}$ respectively. Other operations were carried out as per recommendations. The results revealed that the total GDD required during crop growth period was highest in $\mathrm{D}_{2}$ (MW 26) i.e. $480.21^{\circ} \mathrm{Cd}_{\text {day }}{ }^{-1}$ day and it was followed by and $\mathrm{D}_{1}$ (MW 25) was $479.58^{0} \mathrm{Cd} \mathrm{day}^{-1}$ and $\mathrm{D}_{3}$ (MW 27) i.e. $459.74^{0} \mathrm{Cd}_{\text {day }}{ }^{-1}$ respectively. Due to continuous cloudy weather condition, low temperature at maturity to harvesting stage $\left(\mathrm{P}_{4}\right)$ i.e. drying stage required more days and increase duration of crop. In case of varieties, GDD requirement of all the varieties during crop life cycle was for BM-4 $\left(471.27^{\circ} \mathrm{C}\right)$, BM$2002-1\left(465.92^{\circ} \mathrm{C}\right), \mathrm{BM}-2003-2\left(474.24^{\circ} \mathrm{C}\right)$ and BPMR-145 $\left(481.42^{\circ} \mathrm{C}\right)$ respectively during total crop growth period. HTU required during total crop growth period was highest in $\mathrm{D}_{1}$ (MW 25) i.e. $2876.47^{\circ} \mathrm{C}$ day hour as compared to remaining dates of sowing. In case of varieties, $\mathrm{V}_{4}$ (BPMR-145) required highest total HTU i.e. $2849.69^{\circ} \mathrm{C}$ day hour as compared to other three varieties. HTU required during total crop growth period was highest in $\mathrm{D}_{1}$ (MW 25) i.e. $6278.09^{\circ} \mathrm{C}$ day hour as compare to remaining treatments. In case of varieties $\mathrm{V}_{4}$ (BPMR-145) required highest total HTU i.e. $6261.27^{\circ} \mathrm{C}$ day hour as compare to other three varieties. It might be due to genotypical differences in crop duration and yield. 


\section{Introduction}

Green gram locally called as moong or mung [Vigna radiata (L.) Wilczek] belong to the family Leguminoceae, it fixes atmospheric nitrogen and improves soil fertility by adding $20-25 \mathrm{~kg} \mathrm{~N} \mathrm{ha}^{-1}$. The green gram foliage left over after picking of mature pods can either be feed to livestock or it may ploughed as green to manure enrich the soil with organic matter. Mung bean is a short duration crop so it can be grown as catch crop. Due to covering of stand with foliage it is also grown as cover crop, as it checks the erosion by smothering the soil. Temperature is the prime weather variable which affects plant life. Heat unit concept is the agronomic application of temperature effect on plant, which has been employed to correlate phonological development in crops and to predict maturity dates (Nuttonson, 1955).

The different phases of this crop are subjected to the variation in wind speed throughout its lifecycle. Agronomically, the optimum date of sowing for this crop has been demarcated (Rahman et al., 2009, Bhowmick et al., 2006). However, the impact of weather parameter on this important crop is not well studied. As the crop has to pass its lifecycle within a particular atmospheric specification, it is important to study the impact of weather parameter on the crop to demarcate its growing season properly.

Plants require a specific amount of heat to develop from one point in their life cycle to another, such as from emergence to tri-foliate leaf stage. Research has shown that measuring the heat accumulated over time provides a more accurate physiological estimate than counting calendar days. Temperature and Growing degree days (GDD) represents two important spatially-dynamic climatic variables, as both play vital roles in influencing forest development (Borque et al.,
2000) by directly affecting plant functions such as evapo-transpiration, photosynthesis, plant respiration, plant water and nutrient movement. Crop growth refers to an increase in crop weight, height, volume or area over a certain time scale. Development refers to the timing or progress of the crop from one phasic stage to the next. During this progress of the crop through its phases of development, considerable variations in growth may occur. Growing degree days are based on the concept that the real time to attain a phenological stage is linearly related to temperature in the range between base temperature and optimum temperature (Monteith, 1981).

The thermal requirement of mungbean genotypes and found that due to occurrence of higher maximum and minimum temperature that probably accelerated the process of development and as a result duration of 50\% flowering as well as physiological maturity was shortened by 2-3 days in case of first sowing. So early sowing resulted in absorbing sufficient amount of heat units in short time due to high temperature but late sowings (July 25 and August 5) acquired more days to mature (Singh et al.,2010).

\section{Materials and Methods}

A field experiment was conducted during the kharif season of 2015-16 under rainfed condition on the Experimental Farm of the Department of Agricultural Meteorology located at College of Agriculture, Vasantrao Naik Marathwada Krishi Vidyapeeth, Parbhani. The experimental site situated at a Latitude, Longitude and Altitude of $19^{0} 16^{\prime} \mathrm{N}$, $76^{\circ} 47^{\prime} \mathrm{E}$ and $409 \mathrm{~m}$, respectively.

An experiment was laid out in split plot design with three replications. Treatment under study were four sowing dates in kharif season i.e. $\mathrm{D}_{1}$ $\left(25^{\text {th }} \mathrm{MW}\right), \mathrm{D}_{2}\left(26^{\text {th }} \mathrm{MW}\right)$ and $\mathrm{D}_{3}\left(27^{\text {th }} \mathrm{MW}\right)$ and four different varieties BM-4, BPMR-145, 
BM-2003-2 and BM-2002-1 were sown with spacing $30 \times 10 \mathrm{~cm}$ on gross plot size $4.5 \mathrm{~m} \mathrm{x}$ $4.0 \mathrm{~m}$ and $3.9 \mathrm{~m} \times 3.6 \mathrm{~m}$ respectively. The weather condition in respect of rainfall, temperature, relative humidity, sunshine hours of the relevant crop growing period were obtained from the Department of Agricultural Meteorology, College of Agriculture, Vasantrao Naik Marathwada Krishi Vidyapeeth, Parbhani.

All energy requirement parameters were calculated for Five duration viz., Sowing to Germination, Germination to Bud emergence, Bud emergence to Flower emergence, Flower emergence to Pod emergence, Pod emergence to Harvest.

The growing degree days (GDD) were worked out by considering the base temperature of $10^{0} \mathrm{C}$. The total growing degree days (GDD) for different phenophases were determined as per Nuttonson (1955).

Accumulated GDD

( ${ }^{0} \mathrm{C}$ day)

$$
\begin{aligned}
& \mathrm{dh} \\
=\sum & {\left[\left(\mathrm{T}_{\max }+\mathrm{T}_{\min }\right) / 2\right]-\mathrm{Tb} }
\end{aligned}
$$

where,

Tmax $=$ Daily maximum temperature $\left({ }^{\circ} \mathrm{C}\right)$

Tmin $=$ Daily minimum temperature $\left({ }^{\circ} \mathrm{C}\right)$

Tbase $=$ Base temperature of $10^{\circ} \mathrm{C}$

And other agrometeorological indices namely Photo-thermal units (PTU), Helio-thermal units (HTU) were determined as per Rajput (1980) and Gudadhe et al., (2013).

Photo-thermal units (PTU), the product of GDD and corresponding day length for that day were computed on daily basis as follows:
$\mathrm{PTU}=\mathrm{GDD} \times$ Day Length

where, day length refers to maximum possible sunshine hours.

Helio-thermal units (HTU), the product of GDD and corresponding actual sunshine hours for that day were computed on daily basis as:

$\mathrm{HTU}=\mathrm{GDD} \times$ Actual Sunshine hours

Growing degree-days, helio-thermal units and photo-thermal units were accumulated from the date of sowing to each date of sampling and a particular date of phenophase to give accumulate indices.

\section{Results and Discussion}

\section{Growing Degree Days (GDD)}

Growing degree-days (GDD) (degree- days) calculated for the duration between Sowing to Germination, Germination to Bud emergence, Bud emergence to Flower emergence, Flower emergence to Pod emergence, Pod emergence to Harvest showed significant difference among four green gram genotype under sown situation. The data presented in Table 1 showed that total GDD required during total crop growth period was highest in $\mathrm{D}_{2}$ (MW 26) $1440.6^{0} \mathrm{C}$ followed by $\mathrm{D}_{1}(\mathrm{MW} 25)$ was $1438.7^{\circ} \mathrm{C}$ day and $\mathrm{D}_{3}$ (MW 27) i.e. $1379.2^{\circ} \mathrm{C}$ day. It is cleared that, when temperature of air was maximum then it will definitely affect GDD of green gram crop.

The data analysis of the growing period indicated higher value of GDD from vegetative to harvesting recorded in BPMR$145\left(1444.2^{0} \mathrm{Cd}\right)$ followed by BM-2003-2 $\left(1422.7^{0} \mathrm{Cd}\right), \mathrm{BM}-4 \quad\left(1413.8^{0} \mathrm{Cd}\right)$ were the lowest GDD value recorded in BM-2002-1 $\left(1397.8^{0} \mathrm{Cd}\right)$ genotype. It might be due to the genotypical differences in crop duration. Similar results were reported by Ransing et al., (2014). 
Table.1 Phenophase wise agrometeorological indices required as influenced by various treatments of green gram during Kharif season sowing dates and Varieties

\begin{tabular}{|c|c|c|c|c|c|c|}
\hline \multicolumn{7}{|c|}{ Growing Degree Days (GDD) } \\
\hline Treatments & $\mathbf{P 1}$ & P2 & P3 & P4 & P5 & Total \\
\hline \multicolumn{7}{|c|}{ Date of sowing } \\
\hline D1 (MW25) & 181.07 & 390.87 & 367.49 & 271.18 & 228.12 & 1438.7 \\
\hline D2 (MW26) & 235.89 & 328.62 & 324.86 & 325.02 & 226.25 & 1440.6 \\
\hline D3 (MW27) & 228.78 & 325.07 & 334.86 & 298.09 & 192.42 & 1379.2 \\
\hline \multicolumn{7}{|c|}{ Varieties } \\
\hline BM-4 & 240.24 & 322.36 & 339.75 & 302.02 & 209.45 & 1413.8 \\
\hline BM-2002-1 & 198.24 & 341.77 & 339.27 & 313.48 & 205.01 & 1397.8 \\
\hline BM-2003-2 & 208.96 & 358.53 & 344.07 & 286.58 & 224.6 & 1422.7 \\
\hline BPMR-145 & 213.76 & 370.08 & 346.52 & 290.3 & 223.6 & 1444.2 \\
\hline \multicolumn{7}{|c|}{ Photo-thermal units (PTU) } \\
\hline \multicolumn{7}{|c|}{ Date of sowing } \\
\hline D1 (MW25) & 2422.5 & 5204.5 & 4829.3 & 3496.7 & 2881.0 & 18834.3 \\
\hline D2 (MW26) & 3148.47 & 4352.49 & 4234.6 & 4157.56 & 2831.95 & 18725.1 \\
\hline D3 (MW27) & 3046.38 & 4285.97 & 4330.2 & 3766.57 & 2383.25 & 17812.4 \\
\hline \multicolumn{7}{|c|}{ Varieties } \\
\hline BM-4 & 3204.29 & 4267.09 & 4425.6 & 3863.49 & 2626.06 & 18386.6 \\
\hline BM-2002-1 & 2643.49 & 4533.7 & 4429.4 & 4002.11 & 2566.7 & 18175.5 \\
\hline BM-2003-2 & 2789.31 & 4752.66 & 4482.6 & 3652.71 & 2805.9 & 18483.2 \\
\hline BPMR-145 & 2852.77 & 4903.88 & 4521.2 & 3709.5 & 2796.4 & 18783.8 \\
\hline \multicolumn{7}{|c|}{ Helio-thermal units (HTU) } \\
\hline \multicolumn{7}{|c|}{ Date of sowing } \\
\hline D1 (MW25) & 1145.45 & 2744.88 & 1761.72 & 1470.44 & 1506.93 & 8629.42 \\
\hline D2 (MW26) & 1676.37 & 1854.18 & 1523.04 & 1937.12 & 1614.18 & 8604.89 \\
\hline D3 (MW27) & 1595.74 & 1730.35 & 1469.04 & 2051.7 & 1035.57 & 7882.4 \\
\hline \multicolumn{7}{|c|}{ Varieties } \\
\hline BM-4 & 1558.84 & 1999.94 & 1580.42 & 1829.37 & 1336.29 & 8304.86 \\
\hline BM-2002-1 & 1396.89 & 2100.83 & 1496.8 & 1924.51 & 1311.66 & 8230.69 \\
\hline BM-2003-2 & 1438.11 & 2183.36 & 1572.22 & 1750.19 & 1460.41 & 8404.29 \\
\hline BPMR-145 & 1496.23 & 2155.08 & 1688.96 & 1774.94 & 1433.88 & 8549.09 \\
\hline
\end{tabular}

\section{Photo-thermal units (PTU)}

The data presented in Table 1 showed that total PTU required during total crop growth period was highest in $\mathrm{D}_{1}$ (MW 25) i.e. $18834.3^{\circ} \mathrm{C}$ day hour as followed by $\mathrm{D}_{2}$ (MW 26) i.e. $18725.1{ }^{\circ} \mathrm{C}$ day hour and $\mathrm{D}_{3}$ (MW 26) i.e.17812.4. In total life cycle of the four green gram genotype the photo-thermal units recorded different in different growth phases. In whole crop growth period harvest valve of PTU was observed in BPMR-145 $\left(18783.8^{\circ} \mathrm{Cd}\right.$ hr) followed by BM-2003-2 $\left(18483.2^{\circ} \mathrm{Cd} \mathrm{hr}\right)$, BM-4 $\left(18386.6^{\circ} \mathrm{Cd} \mathrm{hr}\right)$ and lowest PTU 
observed in BM-2002-1 (18175.5 Cd hr). Similar results were reported by Singh et al., (2011).

\section{Helio-thermal units (HTU)}

The data presented in Table 1 showed that total HTU required during total crop growth period was highest in $\mathrm{D}_{1}(\mathrm{MW} 25)$ i.e. $8629.42^{\circ} \mathrm{C}$ day hour as followed by $\mathrm{D}_{2}(\mathrm{MW}$ 26) i.e.8604.39 ${ }^{0} \mathrm{C}$ day hour and $\mathrm{D}_{3}$ (MW 26) i.e.7882.4.

Helio-thermal units recorded at vegetative, reproductive, maturity and harvesting showed significant variation among four green gram genotypes. Based on the data analysis higher value of HTU were recorded in BPMR-145 $\left(8549.09^{0} \mathrm{Cd} \mathrm{hr}\right)$ followed by BM-2003-2 $\left(8404.29^{\circ} \mathrm{Cd} \mathrm{hr}\right), \mathrm{BM}-4\left(8304.86^{\circ} \mathrm{Cd} \mathrm{hr}\right)$ and lowest value recorded in BM-2002-1 $\left(8230.69^{0} \mathrm{Cd}\right.$ hr). HTU increased with increased in duration of crop. Similar results were reported by Sharma and Sonakiya (1990).

On the basis of observations and analysis of data, total crop growth period was highest in $\mathrm{D}_{1}$ (MW 25) followed by $\mathrm{D}_{2}$ (MW 26) and $\mathrm{D}_{3}$ (MW 26). In case of four different Green gram genotype BPMR-145 recorded highest value of GDD, PTU and HTU respectively, in total crop growth period followed by BM-2003-2, BM-4 and BM-2002-1.This might be due to genotypical differences in crop duration and yield.

\section{References}

Bhowmick M. K., Sadukhan R. and Gupta S. 2006. Comparative performance of mungbean genotypes under varying plant population and fertilizer levels during Kharif Indian J. Pulses Res., 19(2): 225-227.

Bourque C.P.A., Meng, F.R., Gullison, J.J. and Bridgland, J. 2000. Biophysical and potential vegetation growth surfaces for a small watershed in Northern Cape Breton Island, Nova Scotia, Canada, Can. J. For. Res., 30: 1179-1195.

Gudadhe N.N., Neeraj Kumar, Pisal R.R., Mote B.M. and Dhonde M.B. 2013. Evaluation of agrometeorological indices in relation to crop phenology of cotton (Gossippium spp.) and chickpea (Cicer aritinum L.) at Rahuri region of Maharashtra. Trends in Biosciences 6(3): 246-250.

Monteith J.L. 1981. Climatic variation sand growth of crops. Q. J. R. Meteo. Soc., 107: 749-774.

Nuttonson M. Y. 1955. Wheat- climate relationship and the use of phenology in ascertaining the thermal and photo thermal requirement of wheat. American Institute of Crop Ecology, Washington DC, pp. 388.

Rajput R.P., Deshmukh M.R. and Chavan V.K. 1980. Accumulated heat units and phenology relationship in wheat as influenced by planting date under late sown conditions. J. of Agron. and Crop Sci., 159: 345-348.

Ransing D.M., Verma A.K., Meshram M.R., and Paikra P.R. 2014. Nodulation, yield and thermal requirement of mungbean (Vigna radiate L.) genotypes as influenced by date of sowing. International Journal of Agricultural Sciences Vol. 10: issue 2, 638-641.

Rehman A., Khalil S. K., Nigar S., Rehman S., Haq I., Akhtar S., Khan A. Z., Shah S. R. 2009. Phenology, plant height and yield of mungbean varieties in response to planting date. Sarhad J. Agric., 25(2):147-151.

Sharma S. and Sonakiya V.K. 1990. Impact of thermal and heliothermal requirements of chickpea cultivars on phenological 
changes and productivity. Research and Development Reports, 7(1-2): 4146.

Singh G., Ram H., Sekhon H.S., Gill K.K. and Khanna V. 2011. Effect of time of planting on nodulation, growth and seed yield of kharif urdbean genotypes.
Journal of food legumes, 25(2):125127.

Singh G., Sekhon H. S., Ram H., Gill K.K and Sharma P. 2010. Effect of date of sowing on nodulation, growth, thermal requirement and grain yield of kharif mung bean genotypes, J. of Food Legumes 23(2): 132-134.

\section{How to cite this article:}

Bobade, B. R., B. V. Asewar, S. M. Nikam and Dakhore, K. K. 2019. Thermal Requirement of Green Gram (Vigna radiate L.) Varieties at Different Phenological Stages under Varied Weather Condition. Int.J.Curr.Microbiol.App.Sci. 8(12): 925-930. doi: https://doi.org/10.20546/ijcmas.2019.812.118 